\title{
Penggunaan Input Internal Berupa Limbah Padi dalam Budidaya Padi Sawah (Oryza sativa L.)
}

\author{
The Usage of Internal Input in Form Of Rice Waste \\ in rice Field (Oryza sativa L.) Cultivation \\ Cut Nur Ichsan ${ }^{1)}$, Taufan Hidayat ${ }^{1)}$, Maulina ${ }^{2}$ \\ 1) Jurusan Agroteknolog,i Fakultas Pertanian, Universitas Syiah Kuala \\ 2) Program Pasca Sarjana Prodi Agroteknologi, Fakultas Pertanian, Universitas Syiah Kuala \\ Program studi Agroteknologi, Fakultas Pertanian, Universitas Syiah Kuala Kopelma Darussalam, Banda Aceh, Indonesia \\ 2311
}

Diterima 20 Juli 2014; Dipublikasi 1 September 2014

\begin{abstract}
Abstrak
Penggunaan input internal pada budidaya padi dengan pemanfaatan limbah, berupa jerami, sekam, maupun bekatul baik yang difermentasi maupun penggunaan langsung tanpa fermentasi. Limbah padi mempunyai keunggulan berupa kandungan fitan dan salisilik yang tinggi pada bekatul, sekam dan jerami. Penelitian ini bertujuan untuk mengetahui respons tanaman padi (Oryza sativa L.) terhadap jenis dan waktu pemberian pupuk organik serta untuk melihat interaksi antara jenis dan waktu pemberian pupuk organik terhadap pertumbuhan dan hasil tanaman padi. Penelitian ini dilaksanakan di Gampong Geuce Kayee Jato, Kecamatan Banda Raya, Banda Aceh, sejak Juli 2012 sampai Maret 2013. Rancangan percobaan yang digunakan dalam penelitian ini adalah rancangan acak kelompok (RAK) pola faktorial dengan tiga ulangan yang terdiri dari dua faktor yaitu faktor jenis bahan organik (J) terdiri dari enam taraf yaitu $\mathbf{J}_{0}=$ Kontrol, $\mathbf{J}_{1}=$ Kompos, $\mathbf{J}_{2}=$ Dedak halus, $\mathbf{J}_{3}=$ Dedak halus fermentasi, $\mathbf{J}_{4}=$ Dedak kasar, $\mathbf{J}_{5}=$ Dedak kasar fermentasi. Faktor kedua adalah waktu pemberian pupuk organik (W) yang terdiri dari $\mathrm{W}_{1}=$ 1 minggu sebelum tanam, $\mathrm{W}_{2}=1$ minggu setelah tanam. Parameter yang diamati antara lain tinggi tanaman, jumlah anakan, jumlah anakan produktif, panjang daun, lebar daun, panjang malai, umur berbunga, gabah berisi per pot, presentase gabah hampa per pot, dan berat 1000 butir. Hasil penelitian menunjukkan bahwa terdapat interaksi yang sangat nyata antara perlakuan jenis pupuk organik dan waktu pemupukan terhadap pertumbuhan dan hasil tanaman padi. Interaksi terbaik dijumpai pada perlakuan dedak kasar fermentasi dan waktu pemupukan seminggu sebelum tanam. Jenis pupuk organik berpengaruh terhadap pertumbuhan dan hasil tanaman padi. Hasil padi tertinggi diperoleh pada perlakuan jenis pupuk dedak kasar fermentasi. Waktu pemupukan berpengaruh terhadap pertumbuhan dan hasil tanaman padi. Perlakuan waktu pemupukan terbaik adalah seminggu sebelum tanam.
\end{abstract}

Kata kunci: padi sawah, limbah padi, pupuk organik, waktu pemupukan.

\begin{abstract}
This study objectives to determine the response of rice (Oryza sativa L.) to the type and timing of organic fertilizer as well as to see the interaction between the type and timing of organic fertilizers on the growth and yield of rice plants. This research was conducted in the Village Geuce Kayee Jato, District Banda Raya, Banda Aceh, from July 2012 until March 2013. The experimental design used in this study was a randomized block design (RAK) factorial with three replications consisting of two factors: the type of organic material factor $(\mathrm{J})$ consists of six levels ie: $\mathrm{J} 0=$ Control, Compost $=\mathrm{J} 1, \mathrm{~J} 2=$ Bran smooth, $\mathrm{J} 3=$ fine bran fermentation, $\mathrm{J} 4$ = coarse bran, $\mathrm{J} 5$ = coarse bran fermentation. The second factor is the timing of organic fertilizer $(\mathrm{W})$ consisting of $\mathrm{W} 1=1$ week before planting, $\mathrm{W} 2=1$ week after planting. Parameters observed include plant height, number of tillers, number of productive tillers, leaf length, leaf width, panicle length, days to flowering, grain containing per pot, the percentage of empty grains per pot, and 1000 grain weight. The results showed that there were very significant interaction between treatment type and timing of fertilizer organic fertilizer on growth and yield of rice plants. The best interactions found in rough bran fermentation treatment and fertilization time a week before planting. Types of organic fertilizer effect on the growth and yield of rice plants. The highest rice yield was obtained in the treatment of rough bran fermentation fertilizer. When fertilizing effect on the growth and yield of rice plants. The best time of fertilization treatment is a week before planting.
\end{abstract}

Keywords: rice field, rice waste, organic fertilizer, fertilizer timing. 


\section{Pendahuluan}

Padi (Oryza sativa) merupakan komoditas pertanian yang telah beratus-ratus tahun dibudidayakan di Indonesia. Hal ini karena padi mempunyai nilai ekonomis dan sosial yang tinggi, serta peranannya dalam tatanan kehidupan masyarakat Indonesia karena merupakan makanan pokok (Sugeng, 1998). Padi merupakan biota pokok di sawah yang dapat hidup di ekosistem darat dan ekosistem air. Berdasarkan tempat tumbuhnya, dikenal dua jenis padi yakni padi sawah dan padi gogo (Simanjuntak, 2010).

Sejak tahun 1970-an, lahan pertanian mulai diterapkan intensifikasi berupa program panca usahatani yang dititikberatkan pada sarana produksi seperti bibit unggul, pupuk dan pestisida yang dipadukan dengan tindak agronomis seperti pengairan dan penggunaan jarak tanam yang optimal. Program tersebut telah memunculkan banyak masalah seperti terjadinya ledakan hama di banyak tempat. Hal ini terjadi karena pencemaran yang menyebabkan gangguan pada berbagai ekosistem karena terjadinya penurunan kualitas fisik lingkungan. Hal ini menjadi penyebab terjadinya proses degradasi kesuburan lahan pertanian terutama pada lahan sawah yaitu ditunjukkan dengan menurunnya kualitas sifat fisik, kimia, dan biologi tanah yang mengakibatkan rendahnya kandungan bahan organik terutama pada lahan sawah, bahkan juga terjadi penurunan $\mathrm{pH}$ tanah. Kondisi tersebut menuntut penggunaan dosis pupuk anorganik dalam jumlah yang semakin tinggi dan ditambah dengan pemberian bahan pembenah tanah untuk meningkatkan $\mathrm{pH}$, guna mempertahankan tingkat produktivitas yang diinginkan. Kandungan bahan organik pada lahan pertanian terutama lahan sawah semakin menipis hingga kurang dari $2 \%$ bahkan di Pulau Jawa hanya sekitar 1\%. Kondisi normal kesuburan lahan sawah mengandung bahan organik 3-5\% (Badan Litbang Pertanian, 2009).

Sebagai salah satu pembentuk tanah, penambahan bahan organik perlu dilakukan untuk memperbaiki sifat fisik, biologi dan kimia tanah. Bahan organik dengan bantuan jasad renik, merubahnya menjadi humus. Humus ini merupakan perekat yang baik bagi butir-butir tanah saat membentuk gumpalan tanah.Pupuk organik mempunyai beberapa kelemahan disamping kelebihan. Kelemahan utama pupuk organik adalah kandungan hara yang rendah dan sering menjadi sumber infeksi hama dan penyakit (Musnamar, 2005).

Pemberian pupuk organik sangat dianjurkan pada tanah-tanah tropika yang digunakan untuk penanaman secara intensif. Bahan organik berperan penting dalam memperbaiki struktur tanah dan kapasitas menahan air di daerah perakaran. Selain itu, bahan organik juga berperan dalam memenuhi unsur hara yang dibutuhkan oleh tanaman untuk memenuhi kebutuhan nutrisinya.Pupuk organik merupakan salah satu pupuk yang diberikan pada tanaman baik sebagai pupuk dasar maupun pupuk susulan. Marsono dan Sigit, (2005) menyatakan bahwa pupuk organik adalah pupuk yang berasal dari bahan organik, seperti (jerami, batang pisang, dan hijauan lainnya) dan kotoran hewan (kotoran kambing, sapi, ayam, kelinci, kerbau). Sebelum digunakan, bahan-bahan tersebut terlebih dahulu dikomposkan. Kompos masa kini sering mendapat masukan teknologi baru berupa penggunaan mikroorganisme terpilih.

Penggunaan kompos sebagai pupuk tidak berbeda dengan pupuk kandang. Dapat ditaburkan sebagai media tanam pengisi pot. Dosisnya pun sama dengan pupuk kandang, sekitar 20 ton/ ha tergantung keadaan tanah dan jenis tanaman yang ditanam. Dibandingkan dengan pupuk anorganik, pemberian kompos (juga pupuk kandang) jauh lebih boros. Walaupun harganya lebih murah dari pupuk anorganik, namun karena pemakaiannya banyak, total biaya pupuknya tetap jauh lebih tinggi (Lingga, 2008).

Samekto (2008) menyatakan bahwa pupuk adalah hara tanaman yang umumnya secara alami ada dalam tanah, atmosfer dan dalam kotoran hewan. Namun demikian, hara itu tidak selalu tersedia dalam bentuk yang siap digunakan tanaman atau jumlahnya tidak mencukupi. Jadi, perlu menambahkannya dengan cara menggunakan pupuk untuk membantu tanaman tumbuh mencapai potensi maksimumnya. Pupuk organik yang digunakan dapat berupa sisa-sisa tanaman, pupuk kandang maupun dedak padi yang berasal dari limbah daerah sekitarnya. Penggunaan limbah dapat memperkecil ketergantungan pada input eksternal yang membuat petani tidak mandiri. Sebaliknya penggunaan input internal dari limbah padi dapat meningkatkan kemandirian petani dalam penyediaan pupuk.

Dedak padi merupakan hasil ikutan proses pemecahan kulit gabah, yang terdiri atas lapisan kutikula sebelah luar, hancuran sekam dan 
Sebagian kecil lembaga yang masih tinggi yang mengandung protein, vitamin dan mineral. Produksi dedak padi di Indonesia cukup tinggi per tahun dapat mencapai 4 juta ton. Fosfor pada dedak padi dalam bentuk fitat atau garam fitat. Asam fitat (C6H18O24P6 atau IP6) secara struktural adalah suatu cincin myo-inositol yang mengikat penuh fosfat disekeliling cincin. Fitat pada padi ditemukan pada bagian biji, daun, batang maupun akar. Bagian terbesar terdapat pada bagian butir dan lapisan luarnya merupakan bagian terbesar yang jumlahnya mencapai 23 kali lipat lebih banyak daripada kandungan fitat pada bagian biji (Maga, 1982). Hasil penelitian Sumiati (2005) menunjukkan bahwa dedak padi mengandung fitat 6,9\%. Kadar fitat pada tanaman bergantung pada kadar fosfor dalam tanah, pemupukan tanaman dengan fosfat yang berlebih akan meningkatkan kadar asam fitat atau garam fitat (Saefulhadjar, 2004).

Berdasarkan uraian di atas maka dicoba penggunaan jenis dan waktu pemberian pupuk organik limbah padi untuk memperkaya hara yang ada didalam tanah, sehingga dapat menentukan pertumbuhan tanaman yang terbaik dalam pemberian pupuk. Serta belum diketahui bagaimana pengaruhnya terhadap respons pertumbuhan padi.

\section{Metode Penelitian}

Penelitian dilakukan di Fakultas pertanian Universitas Syiah Kuala, Darussalam dan di Gampong Geuce Kayee Jato, Juli 2012 sampai Maret 2013.Model matematika yang digunakan dalam penelitian ini adalah :

Yi.j.k. $=\mu+\beta \mathrm{i}+\mathrm{Jj}+\mathrm{Wk}+(\mathrm{JW}) \mathrm{jk}+\varepsilon \mathrm{ijk}$ $(\mathrm{i}=1,2,3, \ldots . \mathrm{J} ; \mathrm{j}=1,2,3, \ldots \ldots \mathrm{W} ; \mathrm{k}=1,2,3, \ldots \mathrm{U})$

Keterangan: Yi.j.k.=Pengamatan pada taraf perlakuan jenis ke-i, waktu ke-j, dan ulangan ke-k; $\mu=$ Rata-rata umum, $\beta i=$ pengaruh ulangan ke-i; $\mathrm{Jj}=$ Pengaruh jenis bahan organik ke-j; Wk= Pengaruh waktu pemberian pupuk organik ke-k; $(\mathrm{JW}) \mathrm{jk}=$ Pengaruh interaksi antara jenisbahan organik ke-j dan waktu pemberian pupuk organik ke-k; $\varepsilon$ ijk= Galat percobaan.

Selama ini pengusahaan tanaman kelapa sawit yang dikelola oleh perkebunan rakyat masih sangat terbatas, sehingga hasil yang diperoleh juga belum optimal. Hal ini terjadi akibat beberapa hal yaitu Data yang diperoleh dianalisis dengan uji F. Uji lanjut menggunakan uji beda nyata jujur pada taraf 5\% (BNJ0.05).
$\mathrm{BNJ} 0.05=\mathrm{q} 0.05(\mathrm{P} ; \mathrm{dbA}) \sqrt{\frac{K T A}{r}}$ Keterangan: BNJ0,05= Beda nyata jujur pada taraf 5 $\%, q_{0,05}\left(p ; d b_{A}\right)=$ Nilai baku q pada taraf $5 \%$ jumlah perlakuan dan derajat bebas acak. KTA= Kuadrat Tengah Acak, $r$ = Ulangan.

Penelitian ini dilaksanakan dengan persiapan benih,benih dibersihkan dari kotoran fisik, dipisahkan antara yang bernas dan yang kosong. Kemudian benih bernas dikecambahkan dalam petridish yang berisi kertas buram yang dilembabkan sebanyak 3 lembar, setelah benih diletakan dalam petridish, kemudian benih diberi sedikit air.Setelah 4 hari benih sudah dapat dipindahkan kedalam pot. Pengecambahan benih bertujuan untuk mendapatkan benih yang memiliki daya berkecambah yang tinggi dan seragam. Persiapan Media Tanam, tanah diayak terlebih dahulu sebelum dimasukkan kedalam pot, dengan menggunakan ayakan 8 mesh untuk mendapatkan ukuran partikel tanah dengan ukuran yang seragam. Selanjutnya tanah dimasukkan ke dalam 36 pot.Masing-masing pot diisi tanah sebanyak $10 \mathrm{~kg} /$ pot. Pemberian Pupuk, pupuk yang diberikan adalah pupuk organik (kompos, dedak padi halus, dedak padi halus fermentasi, dedak padi kasar, dan dedak padi kasar fermentasi). Masing-masing diberikan $100 \mathrm{~g} /$ pot. Setelah diberikan pupuk, kemudian disiram sampai kapasitas lapang.

Perhitungan :

PupukOrganik/pot $=\frac{\text { BeratTanah } / \text { Pot }}{\text { BeratTanah } / \text { ha }}$ dosis $/$ ha $=\frac{10 \mathrm{~kg} / \mathrm{pot}}{2.000 .000 \mathrm{~kg} / \mathrm{ha}} \times 20.000 \mathrm{~kg} / \mathrm{ha}$ $=0.10 \mathrm{~kg}=100 \mathrm{~g} / \mathrm{pot}$.

Kemudian, penanaman dilakukan setelah benih berkecambah dipilih bibit yang pertumbuhannya normal dan seragam ditanam secara langsung ke media tanam yang telah disiapkan sebanyak 1 bibit perlubang tanam. Pemeliharaan dilakukan dengan penyiraman, penyulaman, penyiangan, dan pemupukan.

Pengamatan yang dilakukan pada fase pertumbuhan tanaman padi adalah sebagai berikut: tinggi tanaman, tinggi tanaman diukur dari pangkal batang sampai keujung daun yang tertinggi. Pengukuran dilakukan pada umur 15, 30, 45, dan 60 hari setelah tanam. Jumlah anakan, jumlah anakan dihitung pada setiap rumpun tanaman pada fase pertumbuhan bibit 
dan anakan dihitung pada umur 15, 30, 45, dan 60 hari setelah tanaman. Jumlah anakan produktif, jumlah anakan produktif dihitung pada saat umur 80 dan 90 hari setelah tanam. Panjang daun $(\mathrm{cm})$, daun yang diukur adalah daun yang muncul pada saat daun ke empat. Diukur pada umur 30, 45, dan 60 hari setelah tanam. Lebar daun $(\mathrm{cm})$ pengukuran dilakukan pada bagian terlebar, diamati pada daun yang muncul pada saat daun ke empat. Dilihat pada umur 30, 45, dan 60 hari setelah tanam. Panjang malai, panjang malai diukur dari buku terakhir sampai ujung malai. Diukur pada umur 80 dan 90 hari setelah tanam. Umur berbunga, umur berbunga dilihat pada saat tanaman berbunga $10 \%$ dari populasi malai dalam setiap pot.Gabah berisi per pot, pengamatan persentase gabah berisi per pot dilakukan pada saat panen dengan menggunakan rumus sebagai berikut :

Persentase gabah berisi:

$=$ Jumlah gabah berisi $\times 100 \%$ Jumlah gabah

Persentase gabah hampa per pot, pengamatan persentase gabah hampa per pot dilakukan saat panen dengan menggunakan rumus sebagai berikut :

Persentase gabah hampa:

$=\underline{\text { Jumlah gabah hampa }} \times 100 \%$

Jumlah gabah

dan Berat 1000 butir Jumlah gabah berisi dipisah 1000 butir, kemudian ditimbang.

\section{Hasil dan Pembahasan}

\section{Pengaruh Jenis Pupuk Organik terhadap Pertumbuhan dan Hasil Tanaman Padi}

Hasil uji $\mathrm{F}$ menunjukkan bahwa jenis pupuk organik berpengaruh sangat nyata terhadap semua parameter yang diamati. Rata-rata parameter yang diamati pada perlakuan jenis pupuk organik dapat dilihat pada Tabel 1.

Tabel 1 menunjukkan bahwa rerata tinggi tanaman umur 15 HST tertinggi dijumpai pada perlakuan kompos yang berbeda nyata dengan perlakuan dedak kasar dan dedak kasar fermentasi, namun tidak berbeda nyata dengan perlakuaan kontrol, dedak halus dan dedak halus fermentasi. Nilai tinggi tanaman umur 30 HST tertinggi dijumpai pada perlakuan kompos yang berbeda nyata dengan perlakuan dedak halus fermentasi, namun tidak berbeda nyata dengan perlakuan lainnya. Nilai tinggi tanaman umur 45 dan 60 HST tertinggi dijumpai pada perlakuan dedak halus yang berbeda nyata dengan perlakuan lainnya.

Nilai rata-rata jumlah anakan tanaman padi pada umur 15 HST tertinggi dijumpai pada perlakuan kontrol yang berbeda nyata dengan perlakuan lainnya. Nilai rata-rata jumlah anakan 30 HST tinggi dijumpai pada perlakuan kontrol yang berbeda nyata dengan perlakuan dedak halus, dedak halus fermentasi, dedak kasar dan dedak kasar fermentasi, namun tidak bebeda nyata dengan perlakuan kompos. Nilai rata-rata jumlah anakan umur 45 HST tertinggi dijumpai pada perlakuan kompos yang berbeda nyata dengan perlakuan lainnya. Nilai rata-rata jumlah anakan umur 60 HST dan jumlah anakan produktif tertinggi dijumpai pada perlakuan dedak halus yang berbeda nyata dengan perlakuan lainnya.

\section{Pengaruh Waktu Pemberian Pupuk Organik} terhadap Pertumbuhan dan Hasil Tanaman Padi

Hasil uji $\mathrm{F}$ menunjukkan bahwa waktu pemberian pupuk organik berpengaruh sangat nyata terhadap tinggi tanaman padi umur 15,30 , 45 HST, jumlah anakan umur 15, 30, 45, 60 HST, panjang daun umur $30 \mathrm{HST}$, lebar daun 30, 45, $60 \mathrm{HST}$, panjang malai 80, 90 HST, umur berbunga, gabah berisi, gabah hampa, berat 1000 butir dan potensial hasil tanaman padi. Waktu pemberian pupuk organik juga berpengaruh nyata terhadap panjang daun umur 60 HST. Akan tetapi berpengaruh tidak nyata terhadap tinggi tanaman $60 \mathrm{HST}$, jumlah anakan produktif dan panjang daun 45 HST. Rata-rata parameter yang diamati pada perlakuan waktu pemberian pupuk organik dapat dilihat pada Tabel 2.

Tabel 2 menunjukkan bahwa rata-rata tinggi tanaman umur 15 dan 30 HST tertinggi dijumpai pada waktu pemberian pupuk seminggu sebelum tanam, yang berbeda nyata dengan waktu pemberian pupuk seminggu setelah tanam. Nilai rata-rata tinggi tanaman pada umur 45 HST tertingi dijumpai pada waktu pemberian pupuk seminggu setelah tanam, yang berbeda nyata dengan waktu pemberian pupuk seminggu sebelum tanam, sementara itu nilai rata-rata tinggi tanaman umur 60 HST cenderung lebih tinggi dijumpai pada waktu pemberian pupuk seminggu setelah tanam meskipun secara statistik berbeda tidak nyata. 
Tabel 1. Karakter pertumbuhan dan hasil tanaman padi pada berbagai jenis pupuk organik

\begin{tabular}{|c|c|c|c|c|c|c|c|c|}
\hline \multirow{2}{*}{\multicolumn{2}{|c|}{ Parameter }} & \multicolumn{6}{|c|}{ Jenis Pupuk } & \multirow{2}{*}{$\mathrm{BNJ}_{0,0}$} \\
\hline & & $\mathrm{J}_{0}$ & $\mathrm{~J}_{1}$ & $\mathbf{J}_{2}$ & $\mathrm{~J}_{3}$ & $\mathrm{~J}_{4}$ & $\mathrm{~J}_{5}$ & \\
\hline \multirow{4}{*}{$\begin{array}{l}\text { Tinggi } \\
\text { Tanaman } \\
(\mathrm{cm})\end{array}$} & $\begin{array}{l}\text { Umur } 15 \\
\text { (HST) }\end{array}$ & $22,45 a b c$ & $23,13 \mathrm{c}$ & $22,35 \mathrm{abc}$ & $22,99 b c$ & $21,84 a$ & $22,23 \mathrm{ab}$ & 0,78 \\
\hline & $\begin{array}{l}\text { Umur } 30 \\
\text { (HST) }\end{array}$ & $41,24 b$ & $42,30 \mathrm{~b}$ & $41,59 b$ & $38,88 \mathrm{a}$ & $41,30 \mathrm{~b}$ & $41,77 b$ & 1,4 \\
\hline & $\begin{array}{l}\text { Umur } 45 \\
\text { (HST) }\end{array}$ & $64,33 \mathrm{a}$ & $73,02 \mathrm{c}$ & $78,32 \mathrm{~d}$ & $66,57 \mathrm{ab}$ & $68,94 b$ & $67,25 b$ & 3,16 \\
\hline & $\begin{array}{l}\text { Umur } 60 \\
\text { (HST) }\end{array}$ & $70,80 \mathrm{a}$ & $83,72 d$ & $92,95 \mathrm{e}$ & $78,85 \mathrm{bc}$ & $80,49 \mathrm{~cd}$ & $77,63 b$ & 3,95 \\
\hline \multirow{6}{*}{$\begin{array}{l}\text { Jumlah } \\
\text { Anakan } \\
\text { (Batang) }\end{array}$} & $\begin{array}{l}\text { Umur } 15 \\
\text { (HST) }\end{array}$ & $1,83 \mathrm{c}$ & $1,67 b$ & $1,67 b$ & $1,67 b$ & $1,33 \mathrm{a}$ & $1,67 b$ & 0,15 \\
\hline & $\begin{array}{l}\text { Umur } 30 \\
\text { (HST) }\end{array}$ & $3,83 \mathrm{~d}$ & $3,83 \mathrm{~d}$ & $3,17 b$ & $3,50 \mathrm{c}$ & $3,00 \mathrm{ab}$ & $2,83 \mathrm{a}$ & 0,28 \\
\hline & Umur 45 & 7,17 & 11,67 & 6,67 & 6,67 & 7,83 & 11,17 & \multirow[b]{2}{*}{0.16} \\
\hline & $\begin{array}{l}(\mathrm{HST}) \\
(\sqrt{\mathrm{x}})\end{array}$ & $(2,65 \mathrm{ab})$ & $(3,37 d)$ & $(2,52 a)$ & $(2,57 a)$ & $(2,79 b)$ & $(3,30 c)$ & \\
\hline & Umur 60 & 8,83 & 15 & 18,67 & 10,67 & 12,5 & 15,83 & \\
\hline & $\begin{array}{l}(\mathrm{HST}) \\
(\sqrt{\mathrm{x}})\end{array}$ & $(2,96 a)$ & $(3,86 \mathrm{~d})$ & $(4,28 \mathrm{e})$ & $(3,26 b)$ & $(3,46 c)$ & $(3,95 \mathrm{~d})$ & 0.19 \\
\hline \multicolumn{2}{|c|}{$\begin{array}{l}\text { Jumlah Anakan } \\
\text { Produktif (Batang) }(\sqrt{ } \mathrm{x})\end{array}$} & $\begin{array}{c}8,00 \\
(2,77 \mathrm{ab})\end{array}$ & $\begin{array}{c}8,33 \\
(2,86 \mathrm{~b})\end{array}$ & $\begin{array}{c}17,00 \\
(4,11 \mathrm{e})\end{array}$ & $\begin{array}{c}6,83 \\
(2,59 a)\end{array}$ & $\begin{array}{c}12,83 \\
(3,54 \mathrm{~d})\end{array}$ & $\begin{array}{c}11,17 \\
(3,23 \mathrm{c})\end{array}$ & 0,23 \\
\hline \multirow{3}{*}{$\begin{array}{l}\text { Panjang } \\
\text { Daun }(\mathrm{cm})\end{array}$} & $\begin{array}{l}\text { Umur } 30 \\
\text { (HST) }\end{array}$ & $30,88 \mathrm{~d}$ & $32,12 d$ & $19,51 \mathrm{a}$ & $26,27 \mathrm{c}$ & $23,00 \mathrm{~b}$ & $34,37 \mathrm{e}$ & 2,07 \\
\hline & $\begin{array}{l}\text { Umur } 45 \\
\text { (HST) }\end{array}$ & $38,66 \mathrm{bc}$ & $38,22 b c$ & $37,26 b$ & $38,34 \mathrm{bc}$ & $35,42 \mathrm{a}$ & $38,75 \mathrm{c}$ & 1,46 \\
\hline & $\begin{array}{l}\text { Umur } 60 \\
\text { (HST) }\end{array}$ & $45,34 b$ & $45,78 b c$ & $46,59 c$ & $45,57 b c$ & $45,62 b c$ & $43,91 \mathrm{a}$ & 1,03 \\
\hline \multirow{3}{*}{$\begin{array}{l}\text { Lebar Daun } \\
(\mathrm{cm})\end{array}$} & $\begin{array}{l}\text { Umur } 30 \\
\text { (HST) }\end{array}$ & $0,80 \mathrm{bc}$ & $0,87 \mathrm{~d}$ & $0,67 \mathrm{a}$ & $0,79 b$ & $0,66 \mathrm{a}$ & $0,85 \mathrm{~cd}$ & 0,05 \\
\hline & $\begin{array}{l}\text { Umur } 45 \\
\text { (HST) }\end{array}$ & $0,84 b$ & $0,92 \mathrm{c}$ & $0,75 \mathrm{a}$ & $0,82 b$ & $0,71 \mathrm{a}$ & $0,90 \mathrm{c}$ & 0,04 \\
\hline & $\begin{array}{l}\text { Umur } 60 \\
\text { (HST) }\end{array}$ & $0,85 \mathrm{a}$ & $0,98 \mathrm{c}$ & $0,87 \mathrm{a}$ & $0,83 \mathrm{a}$ & $0,85 \mathrm{a}$ & $0,92 b$ & 0,04 \\
\hline \multirow{2}{*}{$\begin{array}{l}\text { Panjang } \\
\text { Malai }(\mathrm{cm})\end{array}$} & $\begin{array}{l}\text { Umur } 80 \\
\text { HST }\end{array}$ & $19,25 b$ & $17,63 \mathrm{a}$ & $18,57 b$ & $17,49 a$ & $19,30 \mathrm{~b}$ & $20,58 \mathrm{c}$ & 0,84 \\
\hline & $\begin{array}{l}\text { Umur } 90 \\
\text { HST }\end{array}$ & $20,40 \mathrm{a}$ & $19,98 \mathrm{a}$ & $22,93 \mathrm{c}$ & $20,83 a$ & $21,97 b$ & $21,90 \mathrm{~b}$ & 0,89 \\
\hline \multirow{2}{*}{\multicolumn{2}{|c|}{$\begin{array}{l}\text { Umur Berbunga (Hari) } \\
\text { Gabah Berisi (Biji) }\end{array}$}} & $75,00 \mathrm{~b}$ & $75,00 \mathrm{~b}$ & $74,67 \mathrm{ab}$ & $75,17 b$ & $76,83 \mathrm{c}$ & $74,00 \mathrm{a}$ & 0,79 \\
\hline & & $70,56 a$ & $74,88 \mathrm{ab}$ & $73,38 \mathrm{ab}$ & $71,28 \mathrm{a}$ & $73,34 \mathrm{ab}$ & $77,28 b$ & 4,98 \\
\hline \multicolumn{2}{|c|}{ Gabah Hampa (biji) $(\sqrt{ } \mathrm{x})$} & $\begin{array}{c}29,44 \\
(5,19 b)\end{array}$ & $\begin{array}{c}27,87 \\
(5,22 \mathrm{~b})\end{array}$ & $\begin{array}{c}26,45 \\
(5,05 \mathrm{~b})\end{array}$ & $\begin{array}{c}33,72 \\
(5,70 \mathrm{c})\end{array}$ & $\begin{array}{c}26,66 \\
(5,05 \mathrm{~b})\end{array}$ & $\begin{array}{c}19,39 \\
(4,32 \mathrm{a})\end{array}$ & 0,44 \\
\hline \multicolumn{2}{|c|}{ Berat 1000 Butir (g) } & $31,20 \mathrm{a}$ & $48,62 b$ & $84,24 \mathrm{e}$ & $57,80 \mathrm{c}$ & $63,31 d$ & $47,86 \mathrm{~b}$ & 5,05 \\
\hline
\end{tabular}

Keterangan: Angka yang diikuti oleh huruf yang sama pada baris yang sama berbeda tidak nyata pada taraf $5 \%$ (Uji BNJ0.05); ( ) : angka setelah transformasi ( $\sqrt{ } \mathrm{x})$; J0 : kontrol; J1: kompos; J2 : dedak halus; J3 : dedak halus fermentasi; J4 : dedak kasar; J5 : dedak kasar fermentasi; HST: hari setelah tanam. 
Tabel 2. Karakter pertumbuhan dan hasil tanaman padi pada berbagai waktu berbagai pupuk organik

\begin{tabular}{|c|c|c|c|c|}
\hline \multirow{2}{*}{\multicolumn{2}{|c|}{ Parameter }} & \multicolumn{2}{|c|}{ Waktu Pemberian Pupuk } & \multirow{2}{*}{$\mathrm{BNJ}_{0,05}$} \\
\hline & & $\mathrm{W}_{1}$ & $\mathrm{~W}_{2}$ & \\
\hline \multirow{4}{*}{ Tinggi Tanaman $(\mathrm{cm})$} & Umur 15 (HST) & $23,96 \mathrm{~b}$ & $21,04 \mathrm{a}$ & 0,3 \\
\hline & Umur 30 (HST) & $43,05 b$ & $39,31 \mathrm{a}$ & 0.53 \\
\hline & Umur 45 (HST) & $68,86 a$ & $70,61 b$ & 1,20 \\
\hline & Umur 60 (HST) & 80,53 & 80,94 & - \\
\hline \multirow{4}{*}{ Jumlah Anakan (Batang) } & Umur 15 (HST) & $1,83 \mathrm{~b}$ & $1,44 \mathrm{a}$ & 0,06 \\
\hline & Umur 30 (HST) & $3,72 \mathrm{~b}$ & $3,00 \mathrm{a}$ & 0,11 \\
\hline & Umur 45 (HST) $(\sqrt{ } \mathrm{x})$ & $\begin{array}{c}7,61 \\
(2,70 \mathrm{~b})\end{array}$ & $\begin{array}{c}9,44 \\
(3,03 a)\end{array}$ & 0,06 \\
\hline & Umur $60(\mathrm{HST})(\sqrt{ } \mathrm{x})$ & $\begin{array}{c}12.22 \\
(3,44 a)\end{array}$ & $\begin{array}{l}14.94 \\
(3,81 \mathrm{~b})\end{array}$ & 0,07 \\
\hline \multicolumn{2}{|c|}{$\begin{array}{l}\text { Jumlah Anakan Produktif (Batang) } \\
(\sqrt{x})\end{array}$} & $\begin{array}{l}10,61 \\
(3,20)\end{array}$ & $\begin{array}{l}10,78 \\
(3,17)\end{array}$ & - \\
\hline \multirow{3}{*}{ Panjang Daun (cm) } & Umur 30 (HST) & $25,63 a$ & $29,76 b$ & 0,79 \\
\hline & Umur 45 (HST) & 37,84 & 37,71 & \\
\hline & Umur 60 (HST) & $45,68 b$ & $45,26 \mathrm{a}$ & 0,39 \\
\hline \multirow{3}{*}{ Lebar Daun (cm) } & Umur 30 (HST) & $0,75 \mathrm{a}$ & $0,79 b$ & 0,02 \\
\hline & Umur 45 (HST) & $0,79 a$ & $0,86 b$ & 0,01 \\
\hline & Umur 60 (HST) & $0,84 \mathrm{a}$ & $0,92 b$ & 0,01 \\
\hline \multirow{2}{*}{ Panjang Malai (cm) } & Umur 80 HST & $19,02 b$ & $18,59 a$ & 0,32 \\
\hline & Umur 90 HST & $21,54 b$ & $21,13 a$ & 0,34 \\
\hline \multicolumn{2}{|l|}{ Umur Berbunga (Hari) } & $75,56 b$ & $74,67 \mathrm{a}$ & 0,3 \\
\hline \multicolumn{2}{|l|}{ Gabah Berisi (Biji) } & $75,09 b$ & $71,82 \mathrm{a}$ & 1,89 \\
\hline \multicolumn{2}{|l|}{$\begin{array}{l}\text { Gabah Hampa (biji) } \\
(\sqrt{ } \mathrm{x})\end{array}$} & $\begin{array}{l}24.35 \\
(4.83 a)\end{array}$ & $\begin{array}{l}30.16 \\
(5.34 \mathrm{~b})\end{array}$ & 0,17 \\
\hline \multicolumn{2}{|l|}{ Berat 1000 Butir (g) } & $52.84 \mathrm{a}$ & $58.16 \mathrm{~b}$ & 1,92 \\
\hline
\end{tabular}

Pengaruh Interaksi Antara Jenis Pupuk Organik dan Waktu Pemupukan Terhadap Pertumbuhan dan Hasil Tanaman Padi

Terdapat interaksi yang sangat nyata antara jenis pupuk organik dan waktu pemupukan terhadap pertumbuhan dan hasil padi dengan respon yang bervariasi.adapun gambara interaksi tersebut dapat dilihat pada gambar dibawah ini.

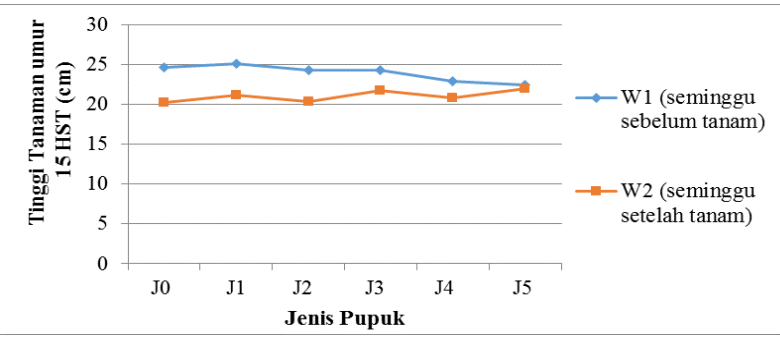

Gambar 1. Interaksi antara jenis dan waktu pemberian pupuk organik terhadap parameter tinggi tanaman umur 15 HST tanaman padi.

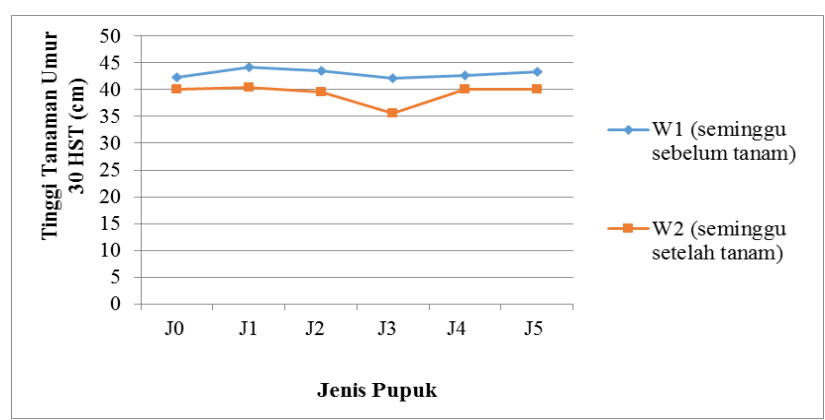

Gambar 2. Interaksi antara jenis dan waktu pemberian pupuk organik terhadap parameter tinggi tanaman umur 30 HST tanaman padi.

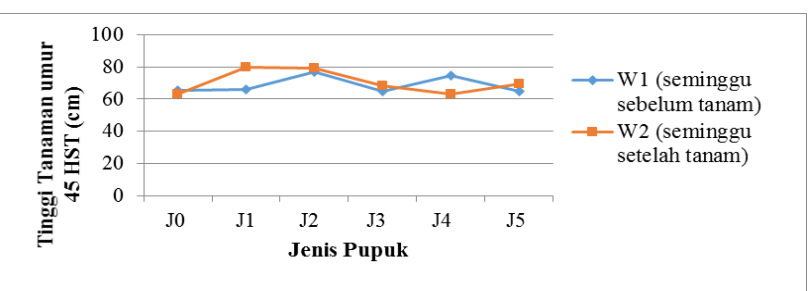


Gambar 3. Interaksi antara jenis dan waktu pemberian pupuk organik terhadap parameter tinggi tanaman umur 45 HST tanaman padi.

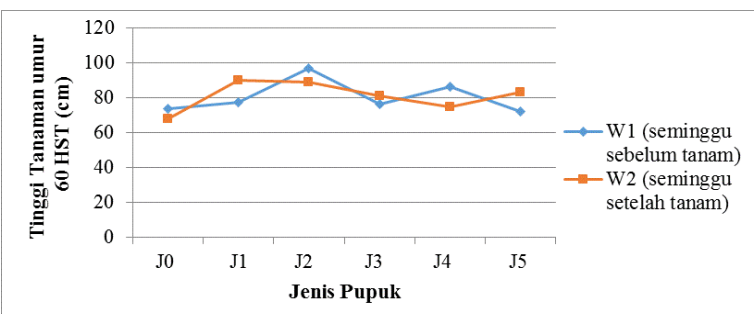

Gambar 4. Interaksi antara jenis dan waktu pemberian pupuk organik terhadap parameter tinggi tanaman umur 60 HST tanaman padi.

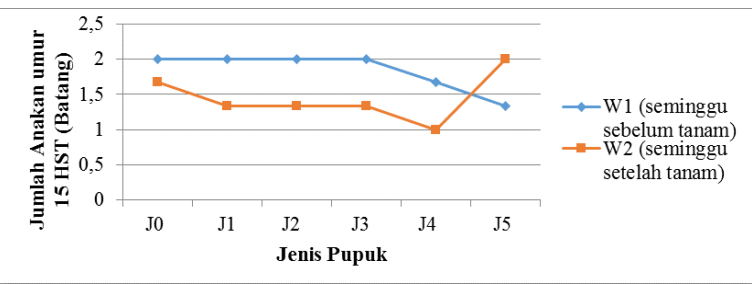

Gambar 5. Interaksi antara jenis dan waktu pemberian pupuk organik terhadap parameter jumlah anakan umur 15 HST tanaman padi.

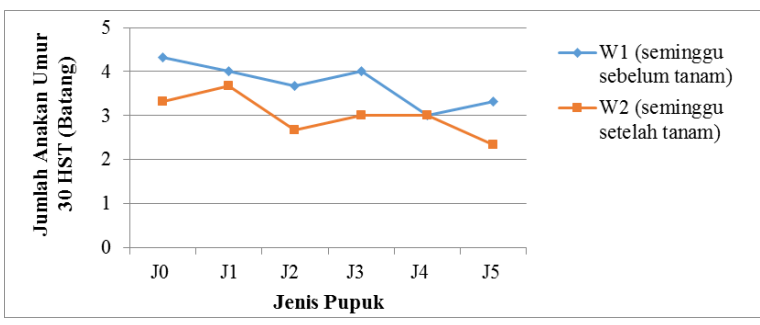

Gambar 6. Interaksi antara jenis dan waktu pemberian pupuk organik terhadap parameter jumlah anakan umur 30 HST tanaman padi.

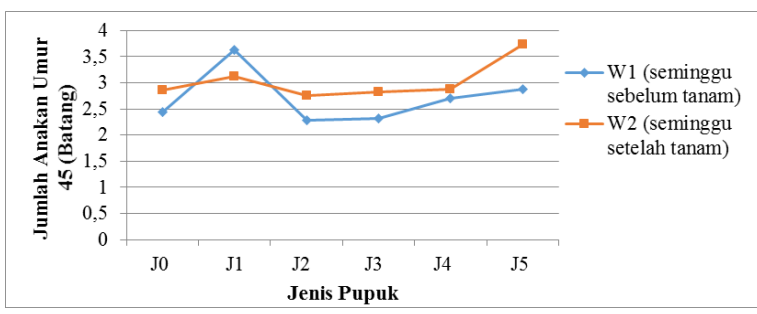

Gambar 7. Interaksi antara jenis dan waktu pemberian pupuk organik terhadap parameter jumlah anakan umur 45 HST tanaman padi.

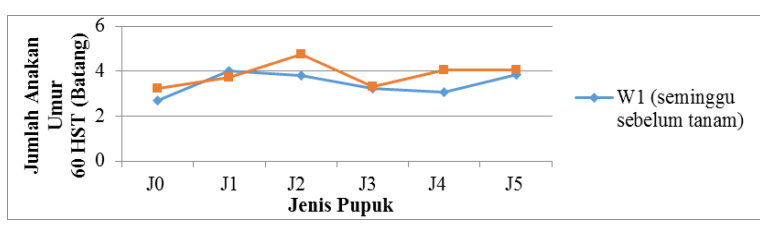

Gambar 8. Interaksi antara jenis dan waktu pemberian pupuk organik terhadap parameter jumlah anakan umur 60 HST tanaman padi.

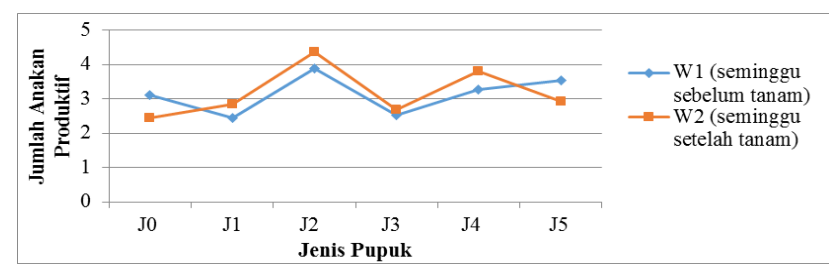

Gambar 9. Interaksi antara jenis dan waktu pemberian pupuk organik terhadap parameter jumlah anakan produktif tanaman padi.

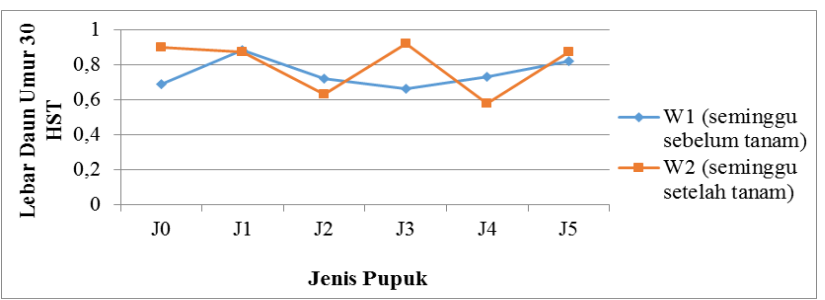

Gambar 10. Interaksi antara jenis dan waktu pemberian pupuk organik terhadap parameter lebar daun tanaman padi umur 30 HST tanaman padi.

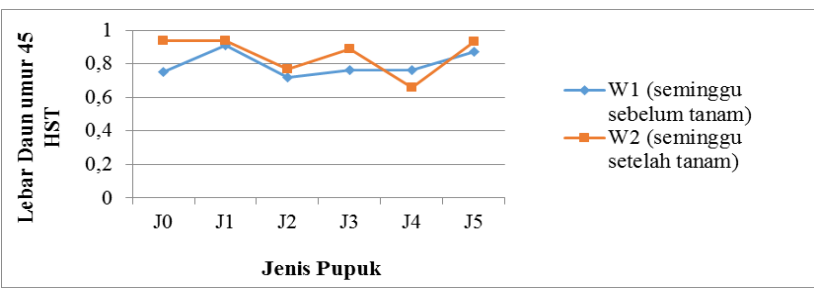

Gambar 11. Interaksi antara jenis dan waktu pemberian pupuk organik terhadap parameter lebar daun tanaman padi umur 45 HST tanaman padi.

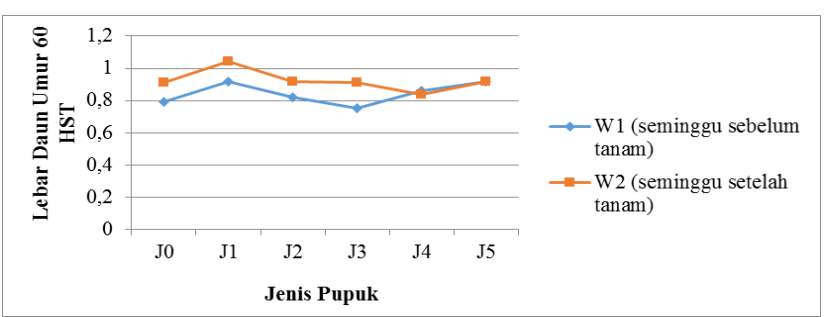

Gambar 12. Interaksi antara jenis dan waktu pemberian pupuk organik terhadap parameter lebar daun tanaman padi umur 60 HST tanaman padi.

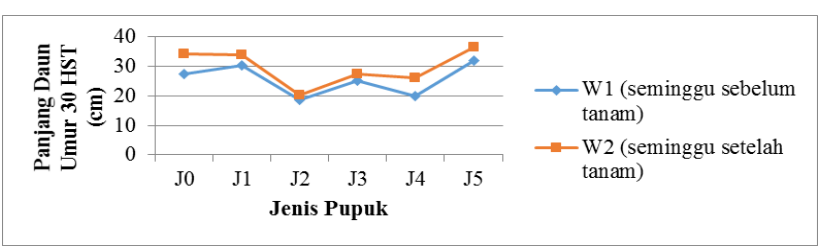

Gambar 13. Interaksi antara jenis dan waktu pemberian pupuk organik terhadap parameter lebar daun tanaman padi umur 30 HST tanaman padi. 


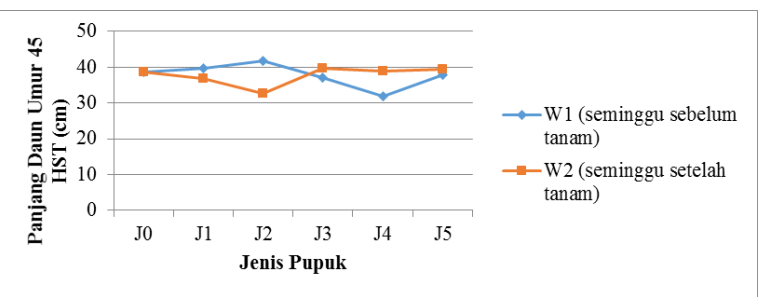

Gambar 14. Interaksi antara jenis dan waktu pemberian pupuk organik terhadap parameter panjang daun tanaman padi umur 45 HST tanaman padi.

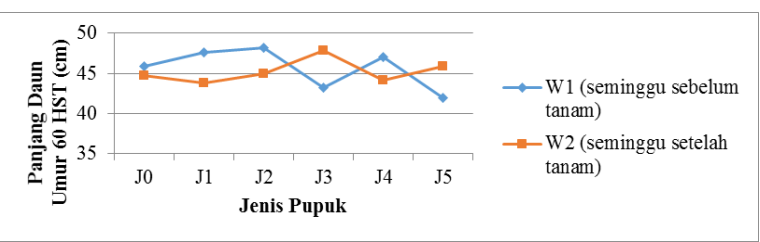

Gambar 15. Interaksi antara jenis dan waktu pemberian pupuk organik terhadap parameter panjang daun tanaman padi umur 60 HST tanaman padi.

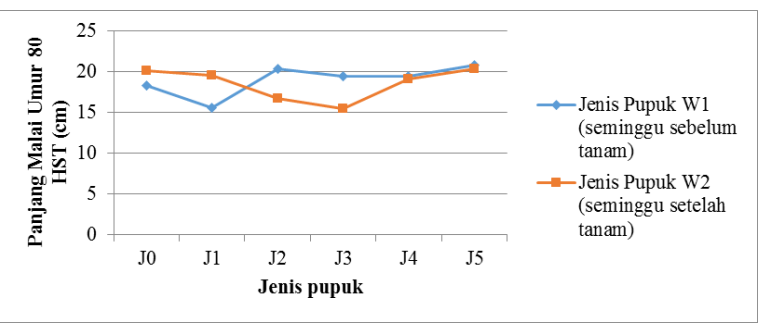

Gambar 16. Interaksi antara jenis dan waktu pemberian pupuk organik terhadap parameter panjang malai tanaman padi umur 80 HST tanaman padi.

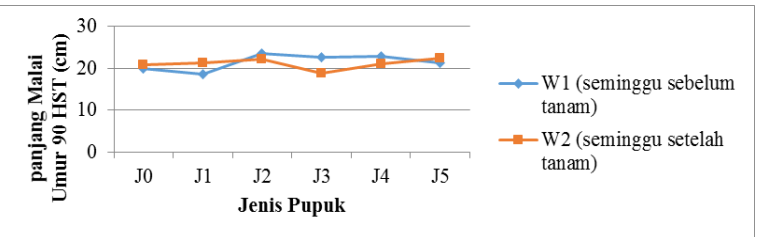

Gambar 17. Interaksi antara jenis dan waktu pemberian pupuk organik terhadap parameter panjang malai tanaman padi umur 90 HST tanaman padi.

\section{Pembahasan}

\section{Pengaruh Jenis Pupuk Organik terhadap Pertumbuhan dan Hasil Tanaman Padi}

Hasil penelitian menunjukkan bahwa perlakuan jenis pupuk organik berpengaruh sangat nyata pada jumlah anakan umur 45 dan 60 HST, jumlah anakan produktif umur 90 HST, panjang daun umur $30 \mathrm{HST}$, dan berat 1000 biji.

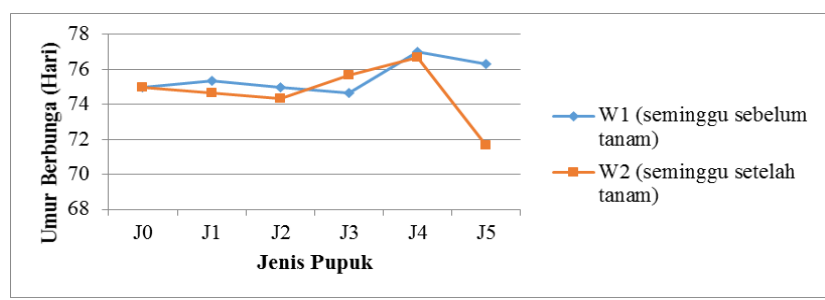

Gambar 18. Interaksi antara jenis dan waktu pemberian pupuk organik terhadap parameter umur berbunga 90 HST tanaman padi.

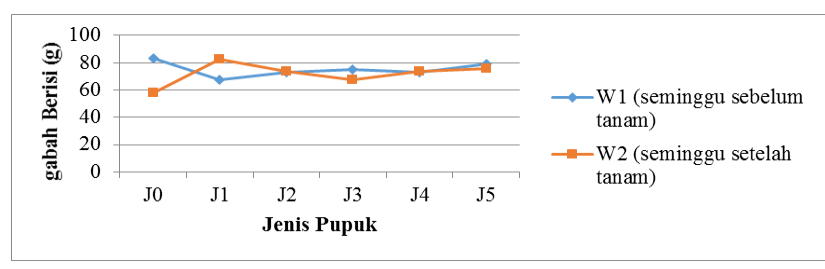

Gambar 19. Interaksi antara jenis dan waktu pemberian pupuk organik terhadap parameter jumlah gabah berisi tanaman padi.

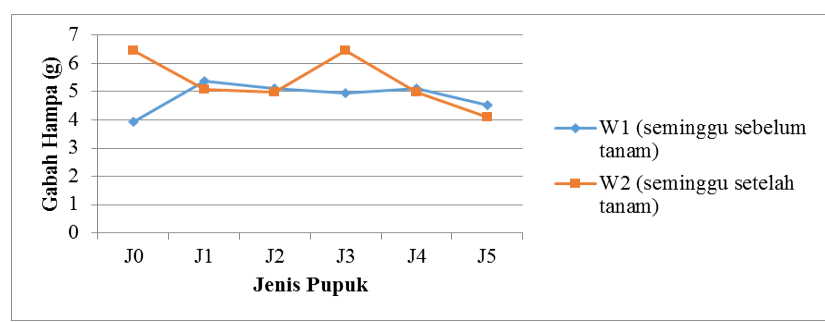

Gambar 20. Interaksi antara jenis dan waktu pemberian pupuk organik terhadap parameter jumlah gabah hampa tanaman padi.

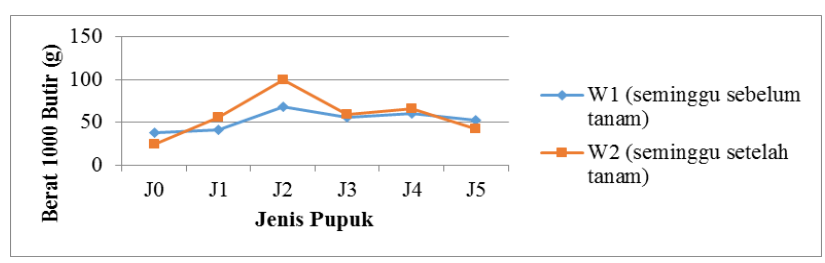

Gambar 21. Interaksi antara jenis dan waktu pemberian pupuk organik terhadap parameter bobot 1000 butir tanaman padi.

Berpengaruh nyata terhadap lebar daun 45 HST, namun berpengaruh tidak nyata terhadap tinggi tanaman umur 15, 30, 45, 60 HST, jumlah anakan umur 15, $30 \mathrm{HST}$, lebar daun umur 30, 60 HST, panjang daun umur 45, 60 HST, panjang malai umur 80, 90 HST, umur berbunga, jumlah gabah berisi dan jumlah gabah hampa. Hal ini dapat terjadi karena pengaruh lingkungan yang berbeda seperti kadar hara, air, dan lingkungan lainnya. Hal ini sejalan dengan 
pendapat Gardner et al. (1991) menyatakan bahwa pertumbuhan serta hasil tanaman dipengaruhi oleh dua faktor yaitu faktor internal dan faktor eksternal. Faktor internal merupakan faktor yang dipengaruhi oleh sifat genetik atau sifat turunan seperti usia tanaman, morfologi tanaman, daya hasil, kapasitas menyimpan cadangan makanan, ketahanan terhadap penyakit dan lain-lain. Faktor eksternal merupakan faktor lingkungan, seperti iklim, tanah dan faktor biotik. Perbedaan pertumbuhan dan hasil yang diperoleh diduga disebabkan oleh satu atau lebih dari faktor tersebut.

Mengingat hanya satu varietas yang digunakan dalam penelitian ini, maka dapat dikatakan bahwa keberagaman pertumbuhan dan hasil yang terjadi bukanlah disebabkan oleh faktor internal atau genetik. Hal ini sejalan dengan pendapat Suryo (1984) perubahan fenotip yang terjadi dapat dibedakan apakah disebabkan oleh faktor lingkungan atau adanya gen mutan. Namun, jika dilihat dari variasi lingkungan yang diberikan pada penelitian ini, diduga faktor lingkungan merupakan penyebab utamanya.

Faktor lingkungan dapat berupa ketersediaan unsur hara di dalam tanah. Hal ini sesuai dengan pendapat Dartius (1990) bahwa ketersediaan unsur-unsur yang dibutuhkan tanaman berada dalam keadaan cukup, maka hasil metabolismenya akan membentuk protein, enzim, hormon dan karbohidrat, sehingga pembesaran, perpanjangan dan pembelahan sel akan berlangsung dengan cepat. Menurut Marsono dan Sigit (2005) pemberian pupuk pada dasarnya bertujuan untuk menambah sejumlah unsur hara terutama unsur hara makro dan mikro yang sangat dibutuhkan oleh tanaman. Rinsema (1993), peranan unsur hara adalah membantu merangsang perkembangan seluruh bagian tanaman sehingga tanaman akan lebih cepat tumbuh, dan penyerapan unsur hara relatif banyak.

Sutejo (1995), pupuk organik memiliki kadar mineral yang rendah dan masih memerlukan pelapukan terlebih dahulu sebelum dapat diserap oleh tanaman. Novizan (2005), pupuk yang mengandung bahan organik tidak dapat langsung dimanfaatkan tanaman, namun sebagian lagi terurai dalam jangka waktu yang lama. Unsur hara yang tidak terurai tidak langsung tersedia bagi tanaman, dengan bantuan jasad renik di dalam tanah akan diubah menjadi bentuk sederhana yang dapat diserap tanaman (Musnamar, 2005).
Pemberian bahan organik seminggu setelah tanam memberikan pertumbuhan yang sama dengan pemberian bahan organik seminggu sebelum tanam dan pada saat tanam. Hal ini menunjukkan bahwa bahan organik dapat diberikan dalam rentang waktu tersebut. Ini diduga karena bahan organik yang diberikan sudah cukup matang sehingga bahan organik tersebut dapat langsung digunakan oleh tanaman dari proses minelisasi yang cepat. Unsur hara yang terkandung di dalam bahan organik tersebut segera tersedia bagi tanaman dan demikian juga efek positif dari bahan organik terhadap sifat fisik dan biologi tanah juga cepat terjadi. Hal ini sejalan dengan pendapat Sanchez (1992) menyatakan bahwa salah satu faktor yang mempengaruhi pertumbuhan awal tanaman adalah kecukupan unsur hara di dalam tanah.

Selain itu, diawal fase pertumbuhan dan perkembangan tanaman padi, kebutuhan akan unsur hara masih sedikit sehingga hara yang tersedia di dalam tanah masih mencukupi untuk mendukung pertumbuhan dan perkembangan tanaman yang optimal. Unsur hara yang tersedia di dalam tanah memberikan kemampuan awal untuk mendukung pertumbuhan dan perkembangan tanaman padi, namun sebaliknya apabila tanah hanya tersedia unsur hara dalam jumlah sedikit dapat mengakibatkan pertumbuhan dan perkembangan tanaman tidak normal (AAK, 1990).

\section{Pengaruh Waktu Pemberian Pupuk Organik terhadap Pertumbuhan dan Produksi Tanaman Padi}

Perbedaan waktu pemberian pupuk berpengaruh sangat nyata pada perlakuan tinggi tanaman umur 15 HST dan jumlah anakan umur 15 HST. Berpengaruh nyata terhadap tinggi tanaman umur 30 HST dan jumlah anakan 30 HST. Akan tetapi berpengaruh tidak nyata terhadap tinggi tanaman 45, $60 \mathrm{HST}$, jumlah anakan 45, $60 \mathrm{HST}$, jumlah anakan produktif umur 90 HST, lebar daun umur 30, 45, 60 HST, panjang daun umur 30, 45, 60 HST, panjang malai umur 80, $90 \mathrm{HST}$, umur berbunga, jumlah gabah berisi, jumlah gabah hampa dan berat 1000 butir.

Pemberian pupuk organik dengan dosis yang sesuai dapat meningkatkan ketersediaan hara, meningkatkan aktivitas mikroorganisme tanah, dan membentuk agregat tanah sehingga dapat mengikat lebih banyak air. Hal ini sejalan dengan pendapat Prihandarini

(2007) 
menyatakan bahwa pemberian pupuk organik bermanfaat untuk meningkatkan efisiensi penggunaan pupuk anorganik dan mem-perbaiki keadaan sifat fisik, kimia dan biologi tanah.

Respon tanaman padi terhadap waktu pemberian pupuk organik bisa tidak sama satu dengan yang lainnya. Suatu varietas bisa memberikan respon yang lebih baik bila pupuk organik diberikan sebelum tanam, sementara varietas lainnya lebih baik bila pupuk organik diberikan setelah tanam. Adisarwanto (2006) menyatakan bahwa keunggulan suatu varietas dipengaruhi oleh interaksi antara faktor genetik varietas dengan kondisi lingkungan tumbuh. Pengelolaan lingkungan tumbuh yang tidak sesuai dapat menyebabkan potensi hasil yang tinggi dari suatu varietas tidak akan muncul.

Soetejo dan Kartasapoetra (1988) waktu aplikasi pupuk juga menentukan pertumbuhan tanaman. Berbedanya waktu aplikasi akan memberikan hasil yang tidak signafikan dengan pertumbuhan tanaman. Sinclair (2003) bahwa tanaman yang memperoleh unsur hara dalam jumlah yang optimum serta waktu yang tepat akan tumbuh dan berkembang secara maksimal.

Peningkatan jumlah gabah berisi serta penurunan jumlah gabah hampa berpengaruh terhadap meningkatnya nilai indeks panen. Hal ini diduga disebabkan adanya penambahan bahan organik pada dosis tersebut menyebabkan terciptanya lingkungan yang ideal bagi perkembangan tanaman padi sehingga prosesproses fisiologis dapat berlangsung dengan baik. Ketersediaan hara di media perakaran yang selanjutnya diangkut ke dalam tubuh tanaman akan tetap menjamin berlangsungnya proses foto-sintesis untuk membentuk asimilat yang pada akhirnya akan ditranslokasikan ke bagian biji (gabah). Semakin banyak asimilat yang ditrans-lokasikan ke biji akan semakin meningkatkan hasil gabah kering. Thamrin (2000) melaporkan bahwa penambahan bahan organik mampu meningkatkan hasil gabah padi kering panen secara nyata.

Pengaruh Interaksi Jenis Pupuk Organik Dengan Waktu Pemupukan terhadap Pertumbuhan dan Hasil Tanaman Padi.

Hasil uji $\mathrm{F}$ menunjukkan bahwa interaksi antara jenis pupuk organik dan waktu pemupukan adalah sangat nyata baik terhadap tinggi tanaman umur 15 HST, 30 HST, 45 HST, dan 60 HST, jumlah anakan umur 15, 30, 45 dan $60 \mathrm{HST}$, jumlah anakan produktif umur $90 \mathrm{HST}$, lebar daun umur 30, 45 dan 60 HST, panjang daun umur 30, 45 dan $60 \mathrm{HST}$, panjang malai, umur berbunga, jumlah gabah berisi, jumkah gabah hampa serta bobot 1000 butir. Hal tersebut bermakna bahwa perbedaan respon tanaman padi akibat perlakuan jenis pupuk saling antara waktu pemupukan dan begitu juga sebaliknya.

Menurut Marsono dan Sigit (2005) pengaruh pupuk sangat penting dalam pertumbuhan dan produksi tanaman. Semakin tepat kandungan unsur hara untuk tanaman maka pertumbuhan dan produksi akan semakin baik. Kebalikannya jika kandungan hara tidak dapat mensuplai kebutuhan hara tanaman maka pertumbuhan akan terhambat dan produksi akan menurun. Dengan demikian pupuk merupakan komponen penting dalam pertumbuhan tanaman.

Pada kondisi optimal, misalnya jika ditanam dalam pot menggunakan tanah mineral, varietas Ciherang merupakan varietas dengan potensi hasil tinggi yaitu dapat menghasilkan 94\% dari hasil tanaman utama (Susilawati, 2011). Potensi hasil tanaman padi berkorelasi tinggi terhadap pening-katan jumlah malai produktif, dimana jumlah anakan merupakan salah satu respon umum tanaman padi terhadap aplikasi jenis pupuk organik. Hal ini terjadi karena meningkatnya serapan $\mathrm{N}, \mathrm{P}$ dan $\mathrm{K}$ oleh tanaman padi yang diaplikasi jenis pupuk organik (Suwandi, 2006).

Fosfor pada dedak padi dalam bentuk fitat atau garam fitat. Asam fitat (C6H18O24P6 atau IP6) secara struktural adalah suatu cincin myoinositol yang mengikat penuh fosfat disekeliling cincin. Fitat pada padi ditemukan pada bagian biji, daun, batang maupun akar. Bagian terbesar terdapat pada bagian butir dan lapisan luarnya merupakan bagian terbesar yang jumlahnya mencapai 23 kali lipat lebih banyak daripada kandungan fitat pada bagian biji (Maga, 1982).

Hasil penelitian Sumiati (2005) menunjukkan bahwa dedak padi mengandung fitat $6,9 \%$. Kadar fitat pada tanaman bergantung pada kadar fosfor dalam tanah, pemupukan tanaman dengan fosfat yang berlebih akan meningkatkan kadar asam fitat atau garam fitat dalam jaringan tanaman (Maga, 1982). Menurut Wahju (1997), dedak padi memiliki kandungan nutrien sebagai berikut: protein kasar (PK) 12\%, serat kasar (SK) 12\%, kalsium (Ca) 0,12\%, posfor (P) 0,21\%, energi metabolis (EM) 1630 $\mathrm{kkal} / \mathrm{kg}$.

Penambahan bahan organik juga dapat meningkatkan kapasitas jerapan karena berbagai gugus fungsional yang dimilikinya. Setiap kation dari unsur hara mikro dan makro dapat berkombinasi dengan senyawa organik. Senyawa 
organik yang bereaksi dengan kation-kation tersebut terdiri dari protein, asam amino, penyusun humus dan asam-asam seperti sitrat dan tartrat. Reaksi kombinasi antara kationkation ini dengan senyawa organik disebut kelasi, sedangkan senyawa komplek hasil bentukannya disebut kelat. Senyawa kelat disamping sebagai pemasok unsur hara mikro dan makro, juga melindungi dari pengendapan unsur tersebut misal-nya oleh ion hidroksil $(\mathrm{OH})$ (Nyakpa, Lubis et al, 1988).

Kompos merupakan media tanam organik yang bahan dasarnya berasal dari proses fermentasi tanaman atau limbah organik, seperti jerami, sekam, daun, rumput, dan sampah kota. Kelebihan dari penggunaan kompos pada media tanam adalah sifatnya yang mampu mengembalikan kesuburan tanah melalui perbaikan sifat-sifat tanah, baik fisik, kimiawi, maupun biologis (Yuwono, 2005).

Perkembangan batang dan perakaran yang baik diperlukan bahan organik yang banyak. Pemakaian kompos sangat dianjurkan karena dapat memperbaiki produktivitas tanah, baik secara fisik, kimia, maupun biologi tanah. Secara fisik kompos bisa menggemburkan tanah, memperbaiki aerase dan draenase; meningkatkan pengikatan partikel-pertikel dan kapasitas mengikat air sehingga dapat mencegah erosi dan longsor, mengurangi tercucinnya nitrogen terlarut serta memperbaiki daya olah tanah (Sima-mora, 2008).

Respons varietas padi terhadap waktu pemberian pupuk organik bisa tidak sama satu dengan yang lainnya. Suatu varietas bisa memberikan respons yang lebih baik bila pupuk organik diberikan sebelum tanam, sementara varietas lainnya lebih baik bila pupuk organik diberikan setelah tanamn. Adisarwanto (2006) menyatakan bahwa keunggulan suatu varietas dipengaruhi oleh interaksi antara faktor genetik varietas dengan kondisi lingkungan tumbuh. Pengelolaan lingkungan tumbuh yang tidak sesuai dapat menyebabkan potensi hasil yang tinggi dari suatu varietas tidak akan muncul.

Selain itu, di awal fase pertumbuhan dan perkembangan tanaman padi, kebutuhan akan unsur hara masih sedikit sehingga hara yang tersedia di dalam tanah masih mencukupi untuk mendukung pertumbuhan dan perkembangan tanaman yang optimal. AAK (1990) menambahkan bahwa, unsur hara yang tersedia di dalam tanah memberikan kemampuan awal untuk mendukung pertumbuhan dan perkembangan tanaman padi, namun sebaliknya apabila tanah hanya tersedia unsur hara dalam jumlah sedikit dapat mengakibatkan pertumbuhan dan perkembangan tanaman tidak normal.

Pemberian bahan organik seminggu setelah tanam memberikan pertumbuhan yang sama dengan pemberian bahan organik seminggu sebelum tanam dan pada saat tanam. Hal ini menunjukkan bahwa bahan organik dapat diberikan dalam rentang waktu tersebut. Ini diduga karena bahan organik yang diberikan sudah cukup matang sehingga bahan organik tersebut cepat berproses di dalam tanah tanpa terjadi reaksi yang negatif. Unsur hara yang terkandung di dalam bahan organik tersebut segera tersedia bagi tanaman dan demikian juga efek positif dari bahan organik terhadap sifat fisik dan biologi tanah juga cepat terjadi. Sanchez (1992) menyatakan bahwa, salah satu faktor yang mempengaruhi pertumbuhan awal tanaman adalah kecukupan unsur hara di dalam tanah.

\section{Kesimpulan}

Jenis pupuk organik berpengaruh terhadap pertumbuhan dan hasil tanaman padi. Hasil padi tertinggi diperoleh pada perlakuan jenis pupuk dedak kasar fermentasi. Waktu pemupukan berpengaruh terhadap pertumbuhan dan hasil tanaman padi. Perlakuan waktu pemupukan terbaik adalah seminggu sebelum tanam. Terdapat interaksi yang sangat nyata antara perlakuan jenis pupuk organik dan waktu pemupukan terhadap pertumbuhan dan hasil tanaman padi. Interaksi terbaik dijumpai pada perlakuan dedak kasar fermentasi dan waktu pemupukan seminggu sebelum tanam.

\section{Daftar Pustaka}

AAK. 1990. Budidaya Tanaman Padi. Penerbit Kanisius, Yogyakarta. $172 \mathrm{hlm}$.

Gardner, F. P., R. B. Pearce, and R. L. Mitchell. 1991. Fisiologi Tanaman Budidaya. Terjemahan oleh: Herawati Susilo. University of Indonesia Press. Jakarta. $428 \mathrm{~h}$.

Lingga. 2008. Petunjuk Penggunaan Pupuk. Penebar Swadaya. Jakarta.

Maga, J.A. 1982. Phytate: Its Chemistry, Occuraence, Food Interactions, Nutritional Significance, and Method of Analysis. J. Agric. and Food Chem. 30 (1) : 1-8. 
Marsono dan P. Sigit. 2005. Pupuk Akar. Penebar Swadaya. Jakarta. $96 \mathrm{hlm}$.

Marsono dan P. Sigit. 2005. Pupuk Akar. Penebar Swadaya. Jakarta. $96 \mathrm{hlm}$.

Musnamar, E. I. 2005. Pupuk Organik Padat: Pembuatan dan Aplikasi. Penebar Swadaya. Jakarta.

Musnamar, E. I. 2005. Pupuk Organik Padat: Pembuatan dan Aplikasi. Penebar Swadaya. Jakarta.

Novizan. 2005. Petunjuk Pemupukan yang Efektif. PT. Agromedia Pustaka, Jakarta. $114 \mathrm{hlm}$.

Nyakpa, M. Y., A. M. Lubis, M. A. Pulung, A.G. Amrah, A. Munawar, G. B. Hong dan N. Hakim. 1988. Kesuburan Tanah. Penerbit Universitas Lampung. 258 hal.

Prihandarani, R. 2007. Teknologi Budidaya Organik. $11 \mathrm{hlm}$. [http//www.biotaman. com]

Rinsema, W. T. 1993. Pupuk dan Pemupukan (terjemahan H. M. Shaleh). Bhatara Karya Aksara. Jakarta. 135 hlm.

Saefulhadjar, D. Iman, H. Kurnia, dan A. Kamil. 2012. Pengaruh Dedak Padi Dalam Ransum Ayam Lokal Yang Diberi Air Minum Mengandung Cemaran Kadmium Terhadap Performans, Fakultas Peternakan UNPAD.

Sanchez, P. A. 1992. Sifat dan Pengolahan Tanah. ITB-Bandung. Jakarta. $397 \mathrm{hlm}$.

Simamora, Suhut dan Salundik. 2008. Peningkatan Kwalitas Kompos. Agromedia Pustaka, Jakarta.

Simanjuntak, Linus. 2010. Usaha Tani Terpadu PATI (Padi, Azolia, Tiktok, dan Ikan). Agromedia Pustaka. Depok.

Sinclair, F. C. and G. Schroth, 2003. Tress, Crops and Soil Fertility: concepts and Research Methods. CABI. 464 P.

Soetejo, M. M dan A.G Kartasapoetra. 1988. Pupuk dan Cara Pemupukan. PT. Bima Aksara. Jakarta. $223 \mathrm{hlm}$.

Sumiati. 2005. Rasio molar asam fitat: Zn untuk menentukan suplementasi $\mathrm{Zn}$ serta penambahan enzim fitase dalam ransum berkadar asam fitat tinggi [disertasi]. Program Pascasarjana, Institut Pertanian Bogor. Bogor

Sumiati. 2005. Rasio molar asam fitat: Zn untuk menentukan suplementasi $\mathrm{Zn}$ serta penambahan enzim fitase dalam ransum berkadar asam fitat tinggi [disertasi]. Program Pascasarjana, Institut Pertanian Bogor. Bogor.

Suryo. 1984. Genetika Strata 1. Gadjah Mada University Press. Yogyakarta. 343h.

Susilawati.2011. Agronomi Ratun GenotipeGenotipe Padi Potensial Untuk Lahan Pasang Surut [Disertasi]. Bogor: Sekolah Pascasarjana IPB.

Suwandi. 2006. Produksi dan formulasi ekstrak kompos kulit udang sebagai biopestisida pengendali penyakit tanaman. Publikasi paten nomor 046.2050.A Direktorat Jenderal Hak Kekayaan Intelektual, Departemen Hukum dan Hak Asasi Manuasia, Jakarta.

Thamrin. 2000. Perbaikan beberapa sifat fisik dan typic kanha-pludults dengan pemberian bahan organik pada tanaman padi sawah. Skripsi. Faperta, Universitas Padjajaran. Bandung.

Yuwono, D. 2005. Kompos. Penebar Swadaya. Jakarta. 